\title{
Phylogenetic and Taxonomic Analyses of Rhodopirellula caenicola Sp. Nov., a New Marine Planctomycetes Species Isolated from Iron Sand
}

\section{Jaewoo Yoon ${ }^{\star}$, Yoshihide Matsuo², Hiroaki Kasai ${ }^{3}$ and Myung-Ki Lee}

${ }^{1}$ College of Pharmacy, Keimyung University, 1095 Dalgubeoldaero, Dalseo-Gu, Daegu 704-701, Republic of Korea ${ }_{2}^{2}$ Marine Biotechnology Institute, 3-75-1 Heita, Kamaishi, Iwate 026-0001, Japan

${ }^{3}$ Marine Biosciences, Kamaishi Research Laboratory, Kitasato University, 160-4 Utou, Okirai, Sanriku-cho, Ofunato, Iwate 022-0101, Japan

${ }^{4}$ Fermentation and Functionality Research Group, Korea Food Research Institute, 516 Baekhyun-dong, Bundang-gu, Sungnam-si, Gyeonggi-do 463-746, Republic of Korea

\begin{abstract}
A Gram-negative, strictly aerobic, pink-pigmented, non-motile, spherical bacterium designated YM26-125 was isolated from iron sand. Phylogenetic analyses based on the 16S rRNA gene sequence indicated that the new strain was affiliated with the phylum Planctomycetes and shared $96.1 \%$ sequence similarity with Rhodopirellula baltica SH $1^{\top}$. The strain could be also differentiated phenotypically from the Rhodopirellula baltica SH $1^{\top}$. The major fatty acids of strain YM26-125 were identified as C16:0 and C18:1 $\omega 9 \mathrm{c}$ as defined by the MIDI system. Amino acid analysis of cell wall hydrolysates indicated that the novel isolate did not contain diaminopimelic acid in their cell walls. The DNA G+C content was determined to be $57.5 \mathrm{~mol} \%$, the major respiratory quinone was identified as menaquinone 6 (MK-6) and a polar lipid profile was present consisting of a phosphatidylglycerol, a diphosphatidylglycerol and three unidentified phospholipids. From the distinct phylogenetic position and combination of genotypic and phenotypic characteristics, the strain is considered to represent a novel species for which the name Rhodopirellula caenicola sp. nov. is proposed. The type strain of $R$. caenicola is YM26-125 $\left(=\right.$ KCTC $32995^{\top}=$ NBRC $\left.110016^{\top}\right)$.
\end{abstract}

Keywords: Planctomycetes; Rhodopirellula caenicola sp. nov; Iron sand; 16S rRNA gene; Polyphasic taxonomy

\section{Introduction}

Members of phylum Planctomycetes [1] constitute a significant proportion of diverse range of natural environments including soil, aquatic freshwater, marine macroalgae and invertebrates [26]. However, the majority of them are uncultivated and the known ecophysiological types of planctomycetes are quite limited [7-9]. The genus Rhodopirellula was first proposed by Schlesner et al. [10]. This genus is affiliated with the family Planctomycetaceae within the phylum Planctomycetes that is a budding and peptidoglycan-less phylogenetic group [11]. At the time of writing, the genus Rhodopirellula (www. bacterio.cict.fr) comprises only one species, Rhodopirellula baltica $\mathrm{SH} 1^{\mathrm{T}}[10]$ and three not yet been validly published members, 'Rhodopirellula rosea' LHWP3 [12], 'Rhodopirellula lusitana' UC17 and 'Rhodopirellula rubra' LF2 [13]. In 2006, in the course of our study on the diversity of culturable marine bacteria in iron sand samples collected from Murohama Beach, Kamaishi, Iwate, Japan, a bacterium, designated YM26-125 , was isolated. Phylogenetic analysis based on the 16S rRNA gene sequences revealed that the novel strain was belonged to the family Planctomycetaceae, with their closest relative being Rhodopirellula baltica SH $1^{\mathrm{T}}$ that is the only validated species. In this study, we characterised a novel marine planctomycete strain, YM26- $125^{\mathrm{T}}$, isolated from iron sand by using polyphasic taxonomic methods, including the $16 \mathrm{~S}$ rRNA gene sequence analysis, physiological, biochemical and chemotaxonomic analyses. Based on the polyphasic taxonomic data, we suggest that the isolate represents a new species of the family Planctomycetaceae within the phylum Planctomycetes.

\section{Materials and Methods}

\section{Isolation of the bacterial strain and culture conditions}

Strain YM26-125 $5^{\mathrm{T}}$ was isolated from iron sand in depth of $30 \mathrm{~cm}$ from the surface collected at Murohama Beach, Kamaishi, Iwate, Japan in July 2006. Iron sand (approximately $1 \mathrm{~g}$ ) was rinsed in $10 \mathrm{~mL}$ of sterile artificial seawater and then collected with a magnet. After more than 10 cycles of rinse and collection, a $50 \mu \mathrm{L}$ of the suspension was spread onto a plate $(\varphi 9 \mathrm{~cm})$ containing medium ' $\mathrm{P}$ ' [14]. The agar medium was incubated for 4 weeks at room temperature and the pink coloured colonies that grew were purified on a fresh marine agar 2216 .

The strain was routinely subcultured on marine agar 2216 at $28^{\circ} \mathrm{C}$ and maintained in marine broth 2216 (Difco) supplemented with $20 \%$ (v/v) glycerol at $-70^{\circ} \mathrm{C}$.

\section{Morphological, physiological and biochemical analysis}

Cell morphology was observed by using transmission electron microscopy (TEM) and motility was measured by phase contrast microscopy (Primo Star; ZEISS). Gliding motility was determined as described by Perry [15]. For TEM, cells were mounted on Formvarcoated copper grids and negatively stained with $1 \%(\mathrm{w} / \mathrm{v})$ aqueous uranyl acetate. Grids were observed using a Hitachi H-7100 microscope operated at $75 \mathrm{kV}$ at a magnification of 20,000. A flagella staining was carried out according to Blenden and Goldberg [16]. The temperature range $\left(4,10,15,20,30,37,40\right.$ and $\left.45^{\circ} \mathrm{C}\right)$ and $\mathrm{pH}$ range (5.5-9.5) for colony growth were determined by incubating the isolate for 2 weeks on marine agar 2216. The following buffers were used for $\mathrm{pH}$ tests: MES (pH 5.5), ACES (pH 6.5 and 7.0), TAPSO (pH 7.6), TAPS (pH 8.5) and CHES ( $\mathrm{pH} 9.0$ and 9.5). The $\mathrm{NaCl}$ concentration for growth was determined on marine agar 2216 containing $0-10 \%(\mathrm{w} / \mathrm{v}) \mathrm{NaCl}$ [17]. Gram-staining was performed using the BD Gram Staining Kit (Becton, Dickinson and Company, USA). Spore formation was tested by staining with malachite green. Anaerobic growth was tested for up to 2 weeks on marine agar 2216 in a jar containing AnaeroPack-Anaero (Mitsubishi Gas Chemical Co, Inc), which works as an $\mathrm{O}_{2}$ absorber and $\mathrm{CO}_{2}$ generator. Catalase activity was detected by the observation of the

*Corresponding author: Jaewoo Yoon, College of Pharmacy, Keimyung University, 1095 Dalgubeoldaero, Dalseo-Gu, Daegu 704-701, Republic of Korea, Tel: +82-53-580-6648; Fax: +82-53-580-6645; E-mail: jwyoon@kmu.ac.kr

Received January 23, 2014; Accepted February 09, 2014; Published February 17,2014

Citation: Yoon J, Matsuo Y, Kasai H (2015) Phylogenetic and Taxonomic Analyses of Rhodopirellula caenicola Sp. Nov., a New Marine Planctomycetes Species Isolated from Iron Sand. J Phylogen Evolution Biol 3: 143. doi:10.4172/23299002.1000143

Copyright: (c) 2015 Yoon J et al. This is an open-access article distributed under the terms of the Creative Commons Attribution License, which permits unrestricted use, distribution, and reproduction in any medium, provided the original author and source are credited. 
formation of bubbles in $3 \%(\mathrm{v} / \mathrm{v}) \mathrm{H}_{2} \mathrm{O}_{2}$ solution. Oxidase activity test was performed using commercial dropper oxidase (Becton, Dickinson and Co). Degradation of DNA was tested using DNase agar [DNase agar (Scharlau Chemie)] [18] , with DNase activity detected by flooding plates with $1 \mathrm{M} \mathrm{HCl}$. Starch hydrolysis were tested as described by Choi et al. [19]. The ability to hydrolyse casein, Tween 20 , Tween 80 and tyrosine were determined according to Hansen and Sørheim [20]. API 20E, API 50CH and API ZYM strips (bioMérieux) were used to determine the physiological and biochemical characteristics. All suspension media for the API test strips were supplemented with $0.85 \%$ (w/v) $\mathrm{NaCl}$ solution (final concentration). API 20E, API 50CH and API ZYM test strips were read after $72 \mathrm{~h}$ incubation at $28^{\circ} \mathrm{C}$. Flexirubintype pigments were investigated by using the bathochromatic shift test with a $20 \%(\mathrm{w} / \mathrm{v}) \mathrm{KOH}$ solution [21].

\section{Determination of DNA G+C content, 16S rRNA gene sequencing and phylogenetic analysis}

Genomic DNA was prepared according to the method of Marmur [22] from cells grown on marine agar 2216 and the DNA base composition was determined by using the HPLC method of Mesbah et al. [23].

An approximately $1,500 \mathrm{bp}$ long fragment of the $16 \mathrm{~S}$ rRNA gene was amplified from the extracted DNA by using bacterial universal primers specific to the $16 \mathrm{~S}$ rRNA gene: $27 \mathrm{~F}$ and 1,492R (Escherichia coli numbering system) [24]. Technical details of phylogenetic and taxonomic analyses were performed according to the method of Liu and Zhao [25]. To ascertain the phylogenetic position of the novel isolate, the 16S rRNA gene sequence of strain YM26-125 (GenBank/ EMBL/DDBJ accession number AB983339) was compared with sequences obtained from GenBank (National Center for Biotechnology Information, http://www.ncbi.nlm.nih.gov). Multiple alignments of the sequences were performed using CLUSTAL_X (version 1.83) [26]. Alignment gaps and ambiguous bases were not taken into consideration when 1,315 bases of the 16S rRNA gene were compared. Evolutionary distances (distance options according to Kimura's twoparameter model) [27] were calculated and clustering was performed with the neighbour-joining method [28], maximum-parsimony (Fitch) [29] and maximum-likelihood [30] methods using MEGA5 software [31]. Bootstrap analysis was used to evaluate the tree topology of the neighbour-joining data by performing 1,000 resamplings [30]. The topology of the phylogenetic tree was evaluated by the bootstrap resampling method of Felsenstein [30] with 1,000 replicates.

\section{Chemotaxonomic analysis}

Gas chromatography analysis of the cellular fatty acid methyl esters was performed using a culture grown on marine agar 2216 at $28^{\circ} \mathrm{C}$ for 7 days and fatty acid methyl esters were extracted and prepared according to standard protocols provided by the MIDI/Hewlett Packard Microbial Identification system Sherlock Version 3.10/TSBA 50 [32]. Cell walls were prepared by the methods described by Schleifer and Kandler [33] and the amino acids present in an acid hydrolysate of the cell walls were identified by TLC (Harper and Davis) [34]. Determination of the respiratory quinone system was carried out as described previously (Collins and Jones) [35].

\section{Results and Discussion}

\section{Morphological, physiological and biochemical characteristics}

Cells of strain YM26-125 $5^{\mathrm{T}}$ grown on marine agar 2216 were coccoid and mostly 1.0-1.1 $\mu \mathrm{m}$ in diameter, devoid of flagella or cell appendages (Figure 1) and produced a pink pigment. Gliding motility was not observed by a light microscopy. Flexirubin-type pigments were not produced. The strain also showed distinct phenotypic, physiological and biochemical features that discriminated it from the closest described member in the genus Rhodopirellula as shown in Table 1.

\section{Molecular phylogenetic analysis}

The almost complete 16S rRNA gene sequence was determined for strain YM26-125 (GenBank/EMBL/DDBJ accession number AB983339). Phylogenetic analysis based on 16S rRNA gene sequences revealed that strain YM26-125 $5^{\mathrm{T}}$ belonged to the genus Rhodopirellula within the phylum Planctomycetes and showed highest sequence similarity (96.1\%) to Rhodopirellula baltica SH $1^{\mathrm{T}}$, which is the only validly described species (Figure 2). Thus, on the basis of phylogenetic data presented, we believe that strain YM26- $125^{\mathrm{T}}$ should be considered as representative of a novel species of the family Planctomycetaceae within the phylum Planctomycetes.

\section{Chemotaxonomic characteristics}

As shown in Table 2, the predominant cellular fatty acids of strain YM26-125 $5^{\mathrm{T}}$ differentiate it from recognized species of the genus Rhodopirellula baltica $\mathrm{SH} 1^{\mathrm{T}}$ based on the proportions of $\mathrm{C} 16: 0$ $(23.2 \%)$ and $\mathrm{C} 18: 1 \omega 9 \mathrm{c}(51.8 \%)$ as defined by the MIDI system. On the basis of the fatty acid composition, strain YM26-125 $5^{\mathrm{T}}$ could be differentiated from the phylogenetically closest taxon Rhodopirellula baltica $\mathrm{SH} 1^{\mathrm{T}}$ as shown in Table 2. Furthermore, strain YM26-125 could be distinguished from the neighbouring species within the genus Rhodopirellula by the presence of C17:0, C16:1 $\omega 11 \mathrm{c}$ and iso-C17:0 and the absence of C10:0.

Amino acid analysis of the cell wall hydrolysates indicated the absence of diaminopimelic acid in the cell wall, which suggests that the strain does not contain peptidoglycan in their cell walls. From these results, it is strongly suggested that strain YM26- $125^{\mathrm{T}}$ represents an independent species of the genus Rhodopirellula within the phylum Planctomycetes.

\section{Polyphasic taxonomic conclusion}

From the distinct phylogenetic position and combinations of genotypic and phenotypic characteristics, strain YM26-125 $5^{\mathrm{T}}$ cannot be assigned to any previously recognized species in the genus Rhodopirellula and thus can be described as representing a novel species, Rhodopirellula caenicola sp. nov.

\section{Description of Rhodopirellula caenicola sp. nov.}

Rhodopirellula caenicola (cae.ni'co.la. L. n. caenum, mud; L: suff. -cola, inhabitant, dweller; N.L. fem. n. caenicola, mud inhabitant). Cells are strictly aerobic cocci that are 1.0-1.1 $\mu \mathrm{m}$ in diameter. Cells lack flagella and are non-motile. Neither cellular gliding movement nor swarming growth is observed. Colonies grown on marine agar 2216 are circular and pink pigmented after 7 days of incubation at $28^{\circ} \mathrm{C}$. Temperature range for growth is $20-30^{\circ} \mathrm{C}$; the optimal temperature is around $28^{\circ} \mathrm{C}$ but no growth occurs at 4 or $45^{\circ} \mathrm{C}$. The $\mathrm{pH}$ range for growth is 6-8 (optimum, pH 7), while no growth was observed below 6 or above $8 . \mathrm{NaCl}$ is required for growth and can be tolerated at a concentration of up to $5 \%(\mathrm{w} / \mathrm{v})$ but no growth occurs above $6 \%(\mathrm{w} / \mathrm{v})$ $\mathrm{NaCl}$. Nitrate and nitrite reduction are negative. Gelatin and urea are hydrolysed but agar, casein, DNA, starch, tyrosine, Tween 20 and Tween 80 are not. The reactions for arginine dihydrolase, $o$-nitrophenyl- $\beta$-Dgalactopyranoside (ONPG), ornithine decarboxylase, citrate utilization and Voges-Proskauer test are positive but hydrogen sulfide production, indole production and lysine decarboxylase activities are negative (API 
Citation: Yoon J, Matsuo Y, Kasai H (2015) Phylogenetic and Taxonomic Analyses of Rhodopirellula caenicola Sp. Nov., a New Marine Planctomycetes Species Isolated from Iron Sand. J Phylogen Evolution Biol 3: 143. doi:10.4172/2329-9002.1000143

Page 3 of 4

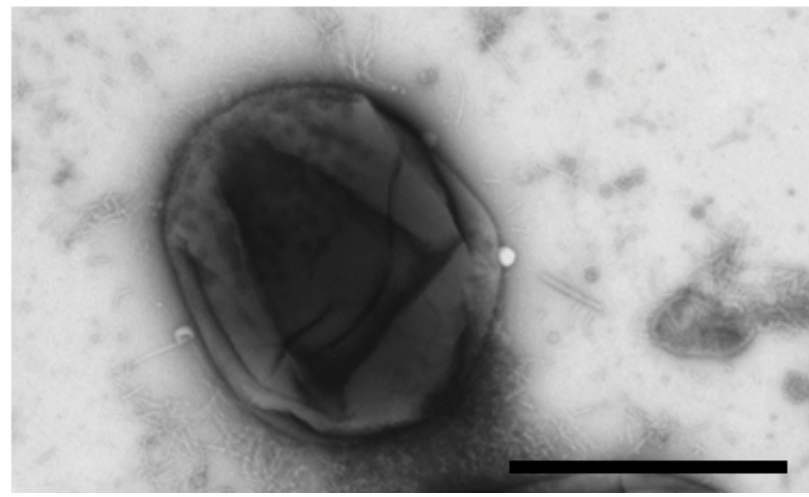

Figure 1: Transmission electron micrograph of a negatively stained cell of strain YM26-125T340. Bar, $1 \mu \mathrm{m}$.

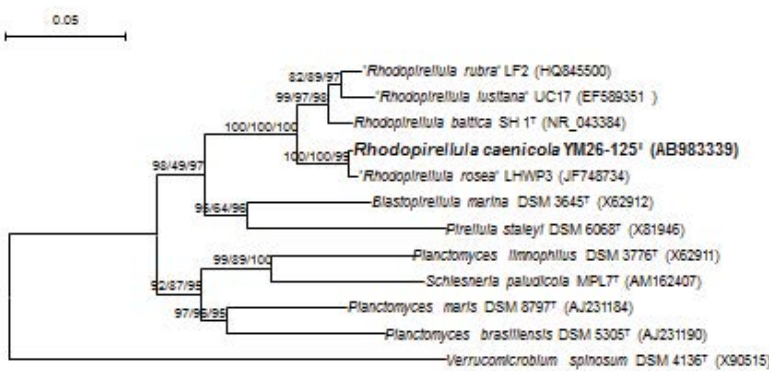

Figure 2: Neighbour-joining tree of 16S rRNA gene sequence similarity, showing the phylogenetic position of strain YM26-125 and representatives of the phylum Planctomycetes. The sequence of Verrucomicrobium spinosum DSM $4136^{\top}$ (X90515) was used as an out group. The sequence determined in this study is shown in bold. Bootstrap values from neighbour-joining, maximumparsimony and maximum likelihood analyses are shown (NJ/MP/ML). Bar, 5\% sequence divergence.

20E). Acid production tests using API50CH strips give the following reactions: acid is produced from L-xylose, $\mathrm{N}$-acetyl-glucosamine, esculin ferric citrate, maltose and melibiose but not from D-arabinose, galactose, glucose, fructose, mannose, arbutin, D-turanose, methyl$\beta$-D-xylopyranoside, salicin, L-arabitol, 5-keto-gluconate, amygdalin, lactose, sucrose, trehalose, starch, glycogen, gentiobiose, L-fucose, ribose, sorbose, rhamnose, sorbitol, methyl- $\alpha-\mathrm{D}$-mannopyranoside, L-arabinose, D-xylose, methyl- $\alpha$-D-glucopyranoside, cellobiose, melezitose, D-lyxose, D-tagatose, D-fucose, inulin, raffinose, glycerol, erythritol, adonitol, dulcitol, inositol, mannitol, xylitol, D-arabitol, gluconate and 2-keto-gluconate. In the API ZYM strip, alkaline phosphatase, esterase (C4), leucine arylamidase, valine arylamidase, naphthol-AS-BI-phosphohydrolase, $\beta$-galactosidase and $\alpha$-fucosidase are present but trypsin, acid phosphatase, $\alpha$-glucosidase, $\beta$-glucosidase, $N$-acetyl- $\beta$-glucosaminidase, esterase lipase (C8), $\alpha$-galactosidase, lipase (C4), cystine arylamidase, $\alpha$-chymotrypsin, $\beta$-glucuronidase and $\alpha$-mannosidase are absent. The major fatty acids are C16:0 (23.2\%) and $\mathrm{C} 18: 1 \omega 9 \mathrm{c}(51.8 \%)$. The major polar lipids are a phosphatidylglycerol, a diphosphatidylglycerol and three unidentified phospholipids. The G+C of the genomic DNA of the type strain is $57.5 \mathrm{~mol} \%$ (Supplementary Figure 1).

The type strain is YM26-125 $\left(=\right.$ KCTC $\left.32995^{\mathrm{T}}=\mathrm{NBRC} 110016^{\mathrm{T}}\right)$, which was isolated isolated from iron sand collected at Murohama Beach, Kamaishi, Iwate, Japan. The GenBank/EMBL/DDBJ accession number of the $16 \mathrm{~S}$ rRNA gene sequence of strain YM $26-125^{\mathrm{T}}$ is AB983339.

\begin{tabular}{|c|c|c|}
\hline Characteristics & 1 & 2 \\
\hline Pigmentation & Pink & Pink to red \\
\hline Cell size $(\mu \mathrm{m})$ & $1.0-1.1$ & $1.0-2.5 \times 1.2-2.3$ \\
\hline Artificial seawater requirement & - & + \\
\hline Temperature range for growth $\left({ }^{\circ} \mathrm{C}\right)$ & $20-30$ & $5-30$ \\
\hline Oxidase & - & + \\
\hline \multicolumn{3}{|l|}{ Hydrolysis of: } \\
\hline Urea & + & - \\
\hline Gelatin & + & - \\
\hline Starch & - & + \\
\hline \multicolumn{3}{|l|}{ Acid production from: } \\
\hline Cellobiose & - & + \\
\hline Fructose & - & + \\
\hline Galactose & - & + \\
\hline Glycerol & - & + \\
\hline Lactose & - & + \\
\hline \multicolumn{3}{|l|}{ Enzyme activity of: } \\
\hline Cystine arylamidase & - & + \\
\hline$\alpha$-Fucosidase & + & - \\
\hline$\alpha$-Glucosidase & - & + \\
\hline$\beta$-Galactosidase & + & - \\
\hline$\beta$-Glucosidase & - & + \\
\hline Polar lipids & $\begin{array}{l}\text { PG, DPG, } \\
\text { 3UPL }\end{array}$ & $P C, P G$ \\
\hline DNA G+C content (mol\%) & 57.5 & 55 \\
\hline
\end{tabular}

Strains: 1 YM26-125 (Rhodopirellula caenicola sp. nov.; present study), 2 Rhodopirellula baltica SH $1^{\top}[10,12]$

Symbols: $P G$ phosphatidylglycerol, DPG diphosphatidylglycerol, UPL unidentified phospholipid, $P C$ phosphatidylcholine, + positive, - negative

Table 1: Differential characteristics of strain YM26 $125^{\top}$ and other closely related taxa.

\begin{tabular}{|c|c|c|}
\hline Fatty acid & 1 & 2 \\
\hline C10:0 & - & 4.9 \\
\hline C12:0 & $\operatorname{tr}$ & - \\
\hline C14:0 & $\operatorname{tr}$ & - \\
\hline C16:0 & 23.2 & 37.6 \\
\hline C17:0 & 3.3 & - \\
\hline C18:0 & 5.8 & 11.3 \\
\hline C16:1 w11c & 2.1 & - \\
\hline $\mathrm{C} 17: 1 \omega 8 \mathrm{c}$ & 4.5 & 3.9 \\
\hline$C 18: 1 \omega 9 c$ & 51.8 & 28.7 \\
\hline iso-C15:0 & $\operatorname{tr}$ & - \\
\hline iso- $\mathrm{C} 17: 0$ & 1.3 & - \\
\hline Summed feature $3^{a}$ & 1.3 & 7.3 \\
\hline \multicolumn{3}{|c|}{$\begin{array}{l}\text { a Summed feature } 3 \text { consists of } \mathrm{C} 16: 1 \omega 7 c \text { and/or } \\
\text { iso- } \mathrm{C} 15: 02-\mathrm{OH} \text {. }\end{array}$} \\
\hline \multicolumn{3}{|c|}{$\begin{array}{l}\text { Strains: } 1 \text { YM26-125 (Rhodopirellula caenicola sp. nov.; present study), } 2 \\
\text { Rhodopirellula baltica } \mathrm{SH} 1^{\top}[12]\end{array}$} \\
\hline \multicolumn{3}{|c|}{$\begin{array}{l}\text { Symbol: } t r \text { trace (less than } 1.0 \%),- \text { not detected. The data were typically obtained } \\
\text { by GLC using the MIDI system. }\end{array}$} \\
\hline
\end{tabular}

Table 2: Comparison of cellular fatty acids for strain YM26-125 ${ }^{\top}$ and other closely related taxa. 
Citation: Yoon J, Matsuo Y, Kasai H (2015) Phylogenetic and Taxonomic Analyses of Rhodopirellula caenicola Sp. Nov., a New Marine Planctomycetes Species Isolated from Iron Sand. J Phylogen Evolution Biol 3: 143. doi:10.4172/2329-9002.1000143

\section{Acknowledgements}

This work was funded by a Grant from Korea Food Research Institute (Project No. E0143023839)

\section{References}

1. Atlas RM (2010) Handbook of microbiological media. 4thedn. Boca Raton: CRC Press, pp. 1009.

2. Bernardet JF, Nakagawa $\mathrm{Y}$, Holmes B; Subcommittee on the taxonomy of Flavobacterium and Cytophaga-like bacteria of the International Committee on Systematics of Prokaryotes (2002) Proposed minimal standards for describing new taxa of the family Flavobacteriaceae and emended description of the family. Int J Syst Evol Microbiol 52: 1049-1070.

3. Blenden DC, Goldberg HS (1965) Silver Impregnation stain for leptospira and flagella. J Bacteriol 89: 899-900.

4. Bondoso J, Albuquerque L, Lobo-da-Cunha A, da Costa MS, Harder J, et al. (2014) Rhodopirellula lusitana sp. nov. and Rhodopirellula rubra sp. nov., isolated from the surface of macroalgae. Syst Appl Microbiol 37: 157-164.

5. Brümmer IH, Felske AD, Wagner-Döbler I (2004) Diversity and seasonal changes of uncultured Planctomycetales in river biofilms. Appl Environ Microbiol 70: 5094-5101.

6. Choi JH, Im WT, Liu QM, Yoo JS, Shin JH, et al. (2007) Planococcus donghaensis sp. nov., a starch-degrading bacterium isolated from the East Sea, South Korea. Int J Syst Evol Microbiol 57: 2645-2650.

7. Chouari R, Le Paslier D, Daegelen P, Ginestet P, Weissenbach J, et al. (2003) Molecular evidence for novel planctomycete diversity in a municipal wastewater treatment plant. Appl Environ Microbiol 69: 7354-7363.

8. Collins CH, Lyne PM (1984) Microbiological Methods, 5thedn. London: Butterworth.

9. Collins MD, Jones D (1981) A note on the separation of natural mixtures of bacterial ubiquinones using reverse-phase partition thin-layer chromatography and high performance liquid chromatography. J Appl Bacteriol 51: 129-134.

10. Derakshani M, Lukow T, Liesack W (2001) Novel bacterial lineages at the (sub) division level as detected by signature nucleotide-targeted recovery of $16 \mathrm{~S}$ rRNA genes from bulk soil and rice roots of flooded rice microcosms. Appl Environ Microbiol 67: 623-631.

11. Elshahed MS, Youssef NH, Luo Q, Najar FZ, Roe BA, et al. (2007) Phylogenetic and metabolic diversity of Planctomycetes from anaerobic, sulfide- and sulfurrich Zodletone Spring, Oklahoma. Appl Environ Microbiol 73: 4707-4716.

12. Felsenstein J (1985) Confidence limits on phylogenies: An approach using the bootstrap. Evolution 39: 783-791.

13. Fitch WM (1971) Towards defining the course of evolution: minimum change for a specific tree topology. Syst Zool 20: 406-416.

14. Fuerst JA (2005) Intracellular compartmentation in planctomycetes. Annu Rev Microbiol 59: 299-328.

15. Garrity GM, Holt JG (2001) The road map to the manual. In: Boone DR Castenholz RW, Garrity GM (eds.) Bergey's manual of systematic bacteriology, vol 1, (2nd edn.) Springer, New York, pp. 119-166.

16. Glöckner FO, Fuchs BM, Amann R (1999) Bacterioplankton compositions of lakes and oceans: a first comparison based on fluorescence in situ hybridization. Appl Environ Microbiol 65: 3721-3726.

17. Hansen GH, Sørheim R (1991) Improved method for phenotypical characterization of marine bacteria. J Microbiol Methods 13: 231-241.

18. Harper JJ, Davis GHG (1979) Two-dimensional thin-layer chromatography for amino acid analysis of bacterial cell walls. Int J Syst Bacteriol 29: 56-58.

19. Izumi H, Sagulenko E, Webb RI, Fuerst JA (2013) Isolation and diversity of planctomycetes from the sponge Niphates sp., seawater, and sediment of Moreton Bay, Australia. Antonie Van Leeuwenhoek 104: 533-546.

20. Noirel J, Simonson T (2008) Neutral evolution of proteins: The superfunnel in sequence space and its relation to mutational robustness. J Chem Phys 129 185104

21. Lee SY, Bollinger J, Bezdicek D, Ogram A (1996) Estimation of the abundance of an uncultured soil bacterial strain by a competitive quantitative PCR method. Appl Environ Microbiol 62: 3787-3793.

22. Liu YW, Zhao CJ (2010) Comprehensive genetic analysis with mitochondrial
DNA data reveals the population evolution relationship between Chinese gamecocks and their neighboring native chicken breeds. Asian J Anim Vet Adv 5(6): 388-401.

23. Marmur $\mathrm{J}$ (1961) A procedure for the isolation of deoxyribonucleic acid from micro-organisms. J Mol Biol 3: 208-218.

24. Mesbah M, Premachandran U, Whitman WB (1989) Precise measurement of the $\mathrm{G}+\mathrm{C}$ content of deoxyribonucleic acid by high-performance liquid chromatography. Int J Syst Bacteriol 39: 159-167.

25. Perry LB (1973) Gliding motility in some non-spreading flexibacteria. J App Bacteriol 36: 227-232.

26. Roh SW, Lee HW, Yim KJ, Shin NR, Lee J, et al. (2013) Rhodopirellula rosea $\mathrm{sp}$. nov., a novel bacterium isolated from an ark clam Scapharca broughtonii. J Microbiol 51: 301-304.

27. Saitou N, Nei M (1987) The neighbor-joining method: a new method for reconstructing phylogenetic trees. Mol Biol Evol 4: 406-425.

28. Sasser M (1990) Identification of bacteria by gas chromatography of cellular fatty acids, MIDI Technical Note 101. Newark, DE: MIDI Inc.

29. Schlesner H, Rensmann C, Tindall BJ, Gade D, Rabus R, et al. (2004) Taxonomic heterogeneity within the Planctomycetales as derived by DNA-DNA hybridization, description of Rhodopirellula baltica gen. nov., sp. nov., transfer of Pirellula marina to the genus Blastopirellula gen. nov. as Blastopirellula marina comb. nov. and emended description of the genus Pirellula. Int J Sys Evol Microbiol 54: 1567-1580.

30. Schleifer KH, Kandler O (1972) Peptidoglycan types of bacterial cell walls and their taxonomic implications. Bacteriol Rev 36: 407-477.

31. Tamura K, Peterson D, Petersen N, Stecher G, Nei M and Kumar S (2011) MEGA5: Molecular evolutionary genetics analysis using Maximum Likelihood, evolutionary distance, and Maximum Parsimony methods. Mol Biol Evol 28 . 2731-2739.

32. Thompson JD, Gibson TJ, Plewniak F, Jeanmougin F, Higgins DG (1997) The CLUSTAL $X$ windows interface: flexible strategies for multiple sequence alignment aided by quality analysis tools. Nucleic Acids Res 25: 4876-4882.

33. Webster NS, Wilson KJ, Blackall LL, Hill RT (2001) Phylogenetic diversity of bacteria associated with the marine sponge Rhopaloeides odorabile. App Environ Microbiol 67: 434-444.

34. Weisburg WG, Barns SM, Pelletier DA, Lane DJ (1991) 16S ribosomal DNA amplification for phylogenetic study. J Bacteriol 173: 697-703.

35. Yoon J, Yasumoto-Hirose M, Matsuo Y, Nozawa M, Matsuda S, et al. (2007) Pelagicoccus mobilis gen. nov., sp. nov., Pelagicoccus albus sp. nov. and Pelagicoccus litoralis sp. nov., three novel members of subdivision 4 within the phylum 'Verrucomicrobia', isolated from seawater by in situ cultivation. Int J Syst Evol Microbiol 57: 1377-1385. 